\title{
Flight Activity of the Stingless Bee Plebeia aff. flavocincta in Tropical Conditions as an Indicator of the General Health of the Colony
}

\author{
ABS Barbosa, hM Meneses, FL Rosa, BM Freitas \\ Universidade Federal do Ceará - UFC, Fortaleza, CE, Brazil
}

\section{Article History}

\section{Edited by}

Evandro Nascimento Silva, UEFS, Brazil

Received

17 December 2019

Initial acceptance 26 October 2020

Final acceptance 28 November 2020

Publication date 28 December 2020

\section{Keywords}

Beekeeping; Colony health; Foraging activities; Meliponini; Tropical bees.

\section{Corresponding author}

Artur Bruno Barbosa

(iD) http://orcid.org/0000-0001-7144-1055

Campus do $\mathrm{PICl}$

Universidade Federal do Ceará - UFC

Avenida Humberto Monte, $\mathrm{s} / \mathrm{n}^{\circ}$

CEP 60356-001, Fortaleza-CE, Brasil.

E-Mail: artur_bruno140@hotmail.com

\begin{abstract}
Bees are prolific pollinators and are responsible for the pollination of most wild and cultivated plants. This study aimed to learn about the flight activity of the stingless bee Plebeia aff. flavocincta in tropical conditions as a parameter to evaluate the general state of the colonies, and to investigate the role of food resources and environmental factors in their flight activities. We recorded the worker flight activity (exit-when they leave the hive; trash-when they discard litter; entry with pollen; and entry without pollen) of four colonies throughout the year and monitored biotic and abiotic conditions that could affect the bee's external activities such as blooming and meteorological conditions. Results show that colonies remained active throughout the year and presented two major periods of external activity; one corresponded to greater food supply in the foraging area, and the other correlated with the time of year when fewer food resources were available. In addition, the four flight activities were all strongly correlated with each other. We concluded that in tropical conditions external activities of $P$. aff. flavocincta are regulated mainly by food availability rather than the prevailing weather conditions. We have found flight activities are an important indicator of the general health of the colony.
\end{abstract}

\section{Introduction}

Bees are prolific pollinators, being responsible for the pollination of most wild and cultivated plants (IPBES, 2016). But recent events have caused significant losses of Apis mellifera colonies, the most common pollinator used for agricultural purpose throughout the world. The generalized use of $A$. mellifera as pollinators has produced an overdependence of most crops on this bee species, pointing to the need to diversify the species of bees used for agricultural pollination. Therefore, recent studies with other species of Apis have been intensified in eastern parts of the globe to identify different pollinators capable of being used efficiently in an agricultural setting. Alternatively, Western nations have focused mainly on species of the genera Megachile, Nomia, Osmia, Centris, Bombus and stingless bees (Magalhães \& Freitas, 2013; Putra et al., 2014; Sterk et al., 2016; Brunet \& Syed, 2017; Cane et al., 2017).
The stingless bees are the most common group of native bees found on the American continent. Due to the large number of species with marked morphological and functional diversities and feeding habits, these bees have become excellent pollinators of wild native flora and have recently attracted interest in agricultural pollination (Kakutani et al., 1993; Kerr, 1996; Nogueira-Neto, 1997; Amano et al., 2000; Slaa et al., 2006; Bomfim et al., 2015). However, studies within this group of bees have been concentrated on medium and large species of the genera Melipona, Scaptotrigona and Trigona. Smaller bees have not been included, such as those of the genus Plebeia (Cruz et al., 2004; Del-Sarto et al., 2005; Greco et al., 2011; Bomfim et al., 2015).

The genus Plebeia is characterized by small bees, usually between 3 and $7.5 \mathrm{~mm}$ (Michener, 2000), which are widely distributed across the tropics and subtropics of the American continent. Members of this genus can be found from southern Mexico to northern Argentina. In Brazil, 21 species 
of this genus are cataloged (Moure et al., 2011; Ascher and Pickering, 2020).

These bees have a lower demand for food resources due to their small size. They present an extremely generalist foraging strategy and demonstrate adaptive plasticity to environmental conditions, which allows them to have a broad geographic distribution and the potential to pollinate small flowers usually not visited by larger bee species (Hrncir \& MaiaSilva, 2013; Lemos, 2014; Silva et al., 2019). To maximize performance, it is important that the colonies are active, strong, and maintain a high reproductive rate to generate greater pollen demand and stimulate foraging behavior in flowers, subsequently pollinating them in the process (Ramalho et al., 1985; Nunes-Silva et al., 2010; Pick \& Blochtein, 2002a).

Activities of the bees either inside the nests or in flight are good indicators of the pollination potential from the colony at any given moment (Nunes-Silva et al., 2013; Lichtenberg et al., 2010; Filmer, 1932; Lemos, 2014). While the bees' activities within the nest reflects the status of the colony, the colony in turn depends directly on the external flight activity of those bees responsible for obtaining food, water, materials for building and maintaining the nest, and waste disposal (Polatto et al., 2014). Therefore, flight activities, including foraging patterns and pollination potential, qualifies as an effective parameter to evaluate the general state of bee colonies. These methods are used frequently and outlined in many publications (Heard, 1999; Pick \& Blochtein, 2002b; Nunes-Silva, 2013).

Environmental factors are a major influence on flight activity. In addition to food availability precipitation, temperature, wind speed and relative humidity have a direct effect on the external activity patterns of the colony (Heard \& Hendrikz, 1993; Hilário et al., 2001; Hilário et al., 2007b; Bartomeus et al., 2011). Usually external conditions have a greater impact on foraging frequency than food availability. This tends to benefit bees that can act in broader temperature and humidity ranges (larger bees), which tend to have an advantage in foraging over smaller bees (Kleinert et al., 2009).

Therefore, it is expected that small bees such as the ones of the genus Plebeia have their foraging activities limited to favorable weather conditions when compared to larger bees. In fact, studies concentrated in Southern Brazil show that $60 \%$ relative humidity is ideal for peak activity of Plebeia emerina and Plebeia saiqui. Minimum temperatures for foraging in $P$. saiqui is $11^{\circ} \mathrm{C}$, but $16^{\circ} \mathrm{C}$ in P. emerina and Plebeia remota (Kleinert-Giovaninni, 1982; Pick \& Blochtein, 2002b). Kleinert-Giovaninni (1982) and Hilário et al. (2007a) examined wind speed and found that $P$. emerina and $P$. remota restrict activities with winds above $4 \mathrm{~m} / \mathrm{s}$ and $5.5 \mathrm{~m} / \mathrm{s}$, respectively. Studies also show that in regions of high latitude, bees of the genus Plebeia present reproductive diapause and decrease or interrupt the colony's external activities due to the unfavorable field conditions in the cold months of the year (Juliani, 1967; Pick \& Blochtein, 2002b).
Nonetheless, there are few studies on species of the genus Plebeia in tropical conditions. Thus, we tested the hypothesis that for the stingless bee Plebeia aff. flavocincta the general state of a colony can be assessed through external activities, which are affected by food availability.

\section{Material and methods}

\section{Study area}

This study was conducted with the stingless bee Plebeia aff. flavocincta between September 2017 and August 2018 in the Bee Unit (Campus do Pici - Universidade Federal do Ceará), located in the city of Fortaleza, Ceará $\left(03^{\circ} 43^{\prime}\right.$ $02^{\prime \prime} \mathrm{S}$ e $38^{\circ} 32^{\prime} 35^{\prime} \mathrm{W}$ and $16 \mathrm{~m}$ of altitude) (IPECE, 2017).

The Bee Unit is located in urban remnants of a Tableland Forest vegetation (Diogo et al., 2014). The characteristic climate of Fortaleza is warm tropical sub-humid, with a rainy season comprising the months of January to May according to the Köppen climate classification (IPECE, 2017). The meteorological parameters were obtained through the automated meteorological station of the Department of Agricultural Engineering (UFC), located approximately 750 $\mathrm{m}$ from the Bee Unit. The average annual rainfall during the study period was $1516.9 \mathrm{~mm}$ with an average temperature of $28.0{ }^{\circ} \mathrm{C}$. The minimum and maximum annual temperature averages were 23.0 and $31.8{ }^{\circ} \mathrm{C}$, respectively. Relative air humidity was $73.5 \%$, insolation was $2,974.7$ hours per year and average wind speed was $3.4 \mathrm{~m} / \mathrm{s}$.

\section{Flight Activity}

The flight activities of the bee $P$. aff. flavocincta were recorded for 5 consecutive days every month in four colonies kept in rational hives between September 2017 and August 2018. Bees entering and leaving a hive were quantified by manual counters for 10 minutes every hour, while there was natural light ( 6 am to $6 \mathrm{pm}$ ), as proposed by Oliveira (1973). The observations were made at the nest entrance for the duration of the daily flight activities. This totaled 2,880 observations, and a sampling effort of 480 hours. The flight behavior of bees was classified in the following categories: exit-when they left to forage; trash-when they came out with materials to be discarded; entry with pollen-when they entered with a visible pollen load in the pollen basket; and lastly entry without pollen-when they entered the colony without apparent pollen load.

\section{Statistical Analysis}

Due to the non-normal distribution of the data, nonparametric analyzes were used. The number of bees performing the flight activities (bee exit, trash, entry with pollen and entry without pollen) was analyzed with a Kruskal-Wallis test, followed by a Dunn test with Bonferroni's adjustment at a significance level of $5 \%(p<0.05)$. This was used to compare 
the different periods of activity throughout the year and to test for temporal variation (dry and rainy season). In addition, a Spearman correlation test was performed to evaluate possible correlations between climatic parameters (temperature, relative humidity, wind speed and precipitation) and flight activities (bee exit, trash, entry with pollen and entry without pollen).

\section{Results}

The colonies of $P$. aff. flavocincta remained active throughout the year, with no interruption of foraging flights (Fig 1). The range of daily flight activity lasted from $6 \mathrm{am}$ to $6 \mathrm{pm}$, with this pattern being consistent throughout the year. Thus, the daily amplitude achieved was 12 hours each day throughout the year.
According to the correlation analysis performed to identify the relationship between meteorological parameters and flight activities, the meteorological parameters that had a significant effect on the bees' behaviors were temperature, relative humidity and wind speed. There was no correlation between flight activities and precipitation. However, it is worth noting that during the rainy season there were no great precipitations at the moments the observations were carried out.

Temperature had a positive but weak correlation with all behavioral parameters (Table 1). The bees $P$. aff. flavocincta began flight activities at 06:00 each morning, with temperatures around $23{ }^{\circ} \mathrm{C}$. Humidity had little influence on behaviors, only impacting trash removal. Wind speed also presented weak correlation with flight activities. There was no correlation with precipitation and flight activities.

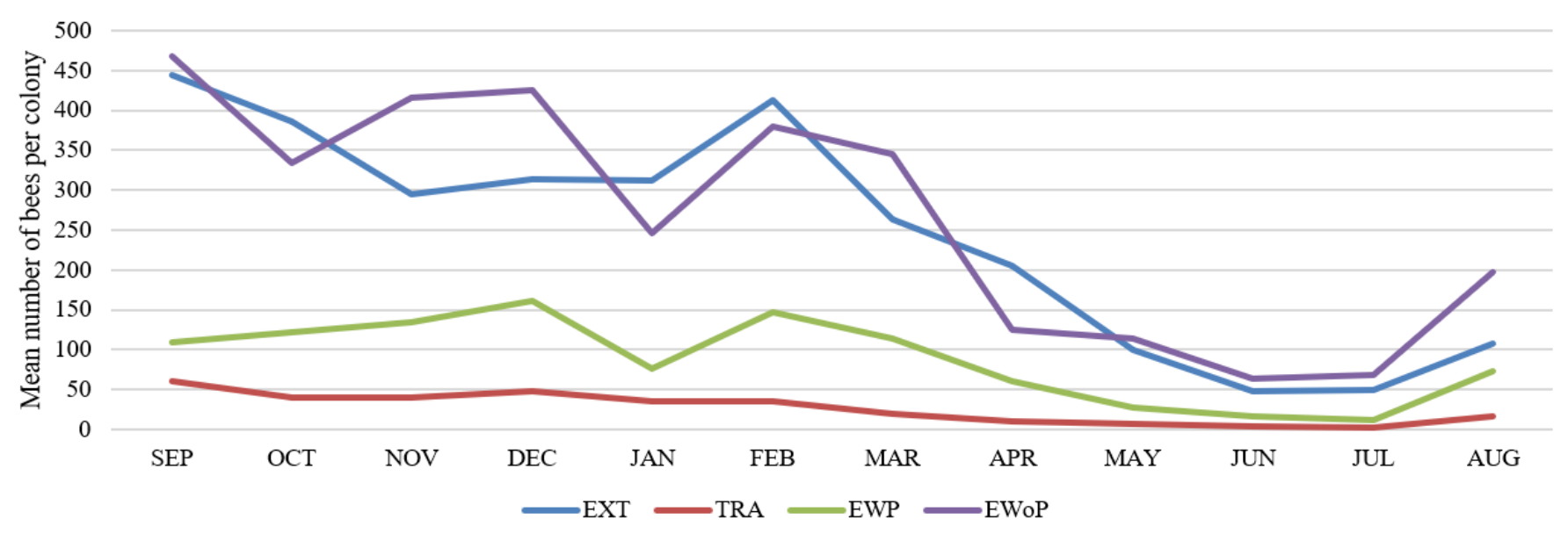

Fig 1. Behavioral parameters of flight activity of Plebeia aff. flavocincta throughout the months of the year; exit (EXT); trash (TRA); entry with pollen (EWP); entry without pollen (EWoP). Values corresponding to ten minutes of observation.

Table 1. Spearman correlation analysis relating the influence of meteorological factors (temperature, relative humidity, wind speed and precipitation) to the flight activities of Plebeia aff. flavocincta; behavioral parameters (BP); temperature (Temp); relative humidity $(\mathrm{RH})$; wind speed (WS); precipitation (Prec); entry with pollen (EWP); entry without pollen (EWoP).

\begin{tabular}{cccccccc}
\hline BP & RH & WS & Prec & Exit & Trash & EWP & EWoP \\
\hline Temp & $-0.6803^{* *}$ & $0.4294^{*}$ & $-0.6255^{* *}$ & $0.3063^{*}$ & $0.3612^{*}$ & $0.2704^{*}$ & $0.3695^{*}$ \\
RH & & $-0.6176^{* *}$ & $0.6521^{* *}$ & -0.1517 & $-0.2963^{*}$ & -0.0109 & -0.228 \\
WS & & & $-0.3207^{*}$ & $0.3353^{*}$ & $0.4714^{*}$ & $0.2383^{*}$ & $0.3631^{*}$ \\
Prec & & & & -0.1235 & -0.1478 & -0.0042 & -0.1954 \\
Exit & & & & & $0.8565^{* *}$ & $0.7759^{* *}$ & $0.9764^{* *}$ \\
Trash & & & & & $0.7634^{* *}$ & $0.8668^{* *}$ \\
EWP & & & & & & & $0.7510^{* *}$ \\
\hline
\end{tabular}

$* p<0.05$

$* * p<0.001$

Based on the data observed in Fig 1, it was possible to distinguish two major periods of external activity: a period of high flight activity (Period 1), which corresponded to the months of September to March; and a period of low flight activity (Period 2), which corresponded to the months of April to August. When the periods of abundance (September to March) and shortage (from April to August) of foraging resources were evaluated, there was a significant difference for all recorded activities (Table 2).

Flight activity differed temporally. For exit behaviors the period of greatest activity was between the months of September and April, while for the hygienic behaviors the greatest activity was recorded between September and February. The period from August to April had the highest 
activity for entry with pollen. Conversely, the period from September to March had the highest amount of entry without pollen (Table 3). These data complement the finding of two distinct periods (Period 1 - large flow of bees, Period 2 reduced flow of bees) in the annual pattern of flight activities of $P$. aff. flavocincta under the study conditions.

Table 2. Average number of bees, followed by standard error, performing the behavioral parameters of flight activity of Plebeia aff. flavocincta from September to March and April to August in Fortaleza/CE.

\begin{tabular}{ccc}
\hline \multirow{2}{*}{ Behavioral Parameters } & \multicolumn{2}{c}{ Average \pm Standard Error } \\
& Sep - Mar & Apr - Aug \\
\hline Exit & $346.36 \pm 7.52 \mathrm{a}$ & $102.46 \pm 7.48 \mathrm{~b}$ \\
Trash & $39.83 \pm 1.22 \mathrm{a}$ & $8.34 \pm 0.64 \mathrm{~b}$ \\
Entry with pollen & $123.74 \pm 2.87 \mathrm{a}$ & $37.97 \pm 2.69 \mathrm{~b}$ \\
Entry without pollen & $372.25 \pm 9.80 \mathrm{a}$ & $113.75 \pm 7.27 \mathrm{~b}$ \\
\hline
\end{tabular}

Difference between letters indicate $\mathrm{p}<0.05$. Values corresponding to ten minutes of observation.

As for bee flights throughout the day, all activities began with a few workers at 06:00 in the morning and the number of bees gradually increased until reaching their peak between 09:00 and 10:00 am. At that moment, the maximum number exiting was 48 bees/min. The maximum entry with pollen was 9 bees/min and entry with nectar or water was 24 bees/min (Fig 2). The exception was the hygienic behavior of throwing away debris produced (trash), whose peak activity was 4 bees/min, between 10:00 am and 12:00 pm (Fig 2). After the peak number of bees recorded, the number of individuals gradually decreased, though it remained high through 04:00 pm. After 04:00 pm activity decreased rapidly (Fig 2).
Table 3. Behavioral parameters of flight activity of Plebeia aff. flavocincta among the months of the year; level of significance $(p)$; exit (EXT); trash (TRA); entry with pollen (EWP); entry without pollen (EWoP).

\begin{tabular}{ccccc}
\hline Months & EXT & TRA & EWP & EWoP \\
\hline SEP & $444.90 \mathrm{a}$ & $60.20 \mathrm{a}$ & $109.85 \mathrm{ab}$ & $467.50 \mathrm{a}$ \\
OCT & $385.95 \mathrm{a}$ & $40.25 \mathrm{ab}$ & $121.37 \mathrm{a}$ & $334.55 \mathrm{abc}$ \\
NOV & $294.70 \mathrm{abc}$ & $40.40 \mathrm{ab}$ & $135.25 \mathrm{a}$ & $415.37 \mathrm{abc}$ \\
DEC & $313.42 \mathrm{ab}$ & $48.32 \mathrm{ab}$ & $160.85 \mathrm{a}$ & $425.55 \mathrm{abc}$ \\
JAN & $311.80 \mathrm{abc}$ & $35.00 \mathrm{abc}$ & $76.20 \mathrm{abc}$ & $245.40 \mathrm{abc}$ \\
FEB & $412.60 \mathrm{a}$ & $34.85 \mathrm{abcd}$ & $146.40 \mathrm{a}$ & $379.55 \mathrm{abc}$ \\
MAR & $262.75 \mathrm{abc}$ & $20.10 \mathrm{bcde}$ & $114.35 \mathrm{ab}$ & $344.50 \mathrm{abc}$ \\
& 205.90 & $10.95 \mathrm{cde}$ & $61.10 \mathrm{abcd}$ & $125.35 \mathrm{bcd}$ \\
APR & $\mathrm{abcd}$ & & & \\
MAY & $100.30 \mathrm{~cd}$ & $7.00 \mathrm{de}$ & $27.80 \mathrm{~cd}$ & $114.40 \mathrm{~cd}$ \\
JUN & $48.60 \mathrm{~d}$ & $4.75 \mathrm{e}$ & $15.90 \mathrm{~d}$ & $63.30 \mathrm{~d}$ \\
JUL & $49.80 \mathrm{~d}$ & $2.10 \mathrm{e}$ & $11.55 \mathrm{~d}$ & $68.95 \mathrm{~d}$ \\
AUG & $107.70 \mathrm{bcd}$ & $16.90 \mathrm{cde}$ & $73.50 \mathrm{abcd}$ & $196.75 \mathrm{bcd}$ \\
\hline
\end{tabular}

Values corresponding to ten minutes of observation.

It is important to emphasize that the sun sets around 06:00 pm each day at the latitude in which this study was conducted.

In the Northeast region of Brazil, and in Ceará in particular, the year is usually divided into two seasons which are dry and rainy. This is determined based on the regular occurrence of rainfall, directly influencing food availability. In the coastal region of Ceará where this experiment was conducted the resource shortage period usually refers to the rainy season and the resource abundance period refers to the dry season, unlike what occurs in inland areas. However, in the comparison of dry and rainy seasons there was no significant difference $(p<0.05)$ in the average number of individuals

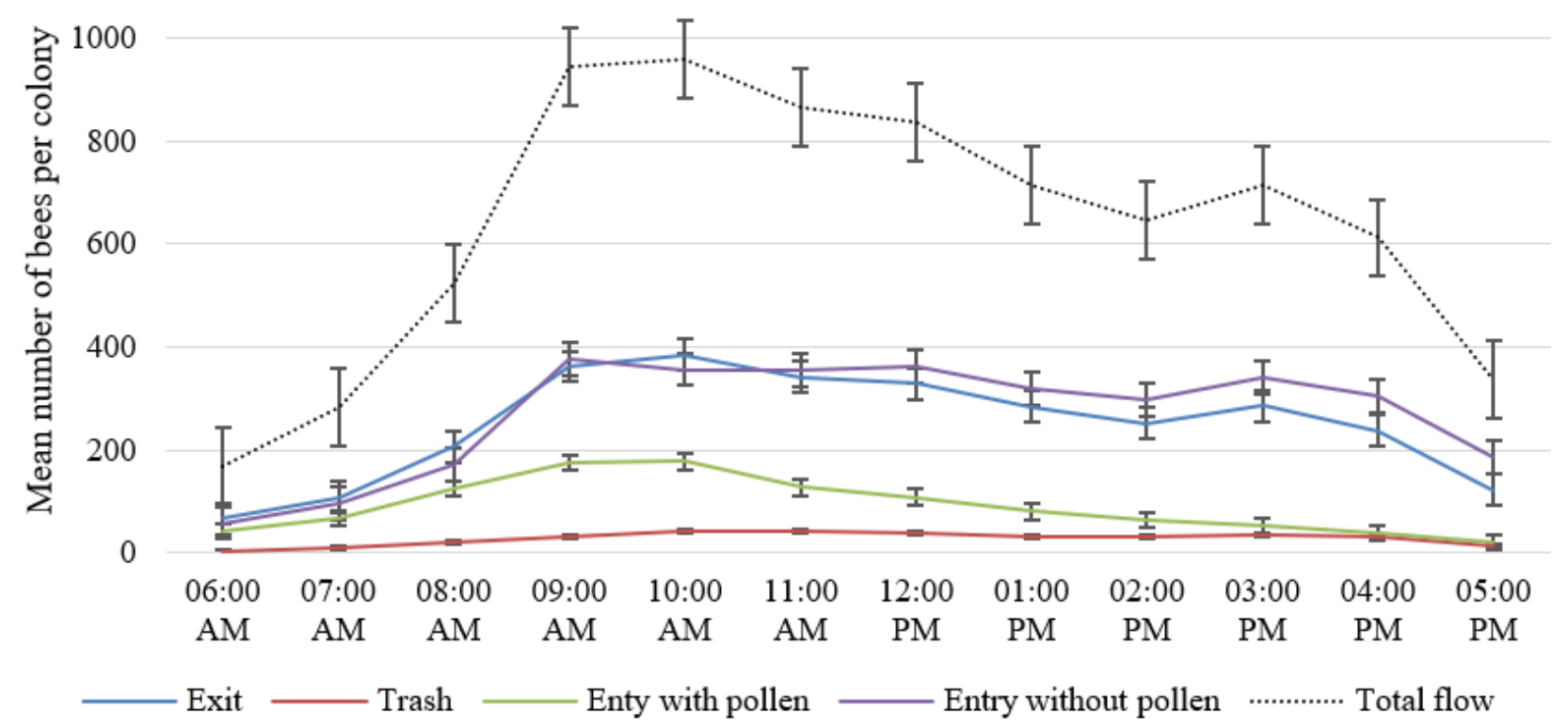

Fig 2. Average number of Plebeia aff. flavocincta bees by colony in flight activity at different times of the day throughout the year. Values corresponding to ten minutes of observation. 
performing flight activities in the hours of the day, except at 5 $\mathrm{pm}$, when there were more bees performing flight activities in the rainy season. This is despite a similar pattern observed for the annual analysis presented in Fig 2, including the highest flight activity occurring between 09:00 and 10:00 am in both seasons (Fig 3). Overall, there were more bees foraging in the dry season than in the rainy season, however there was no significant difference between them.

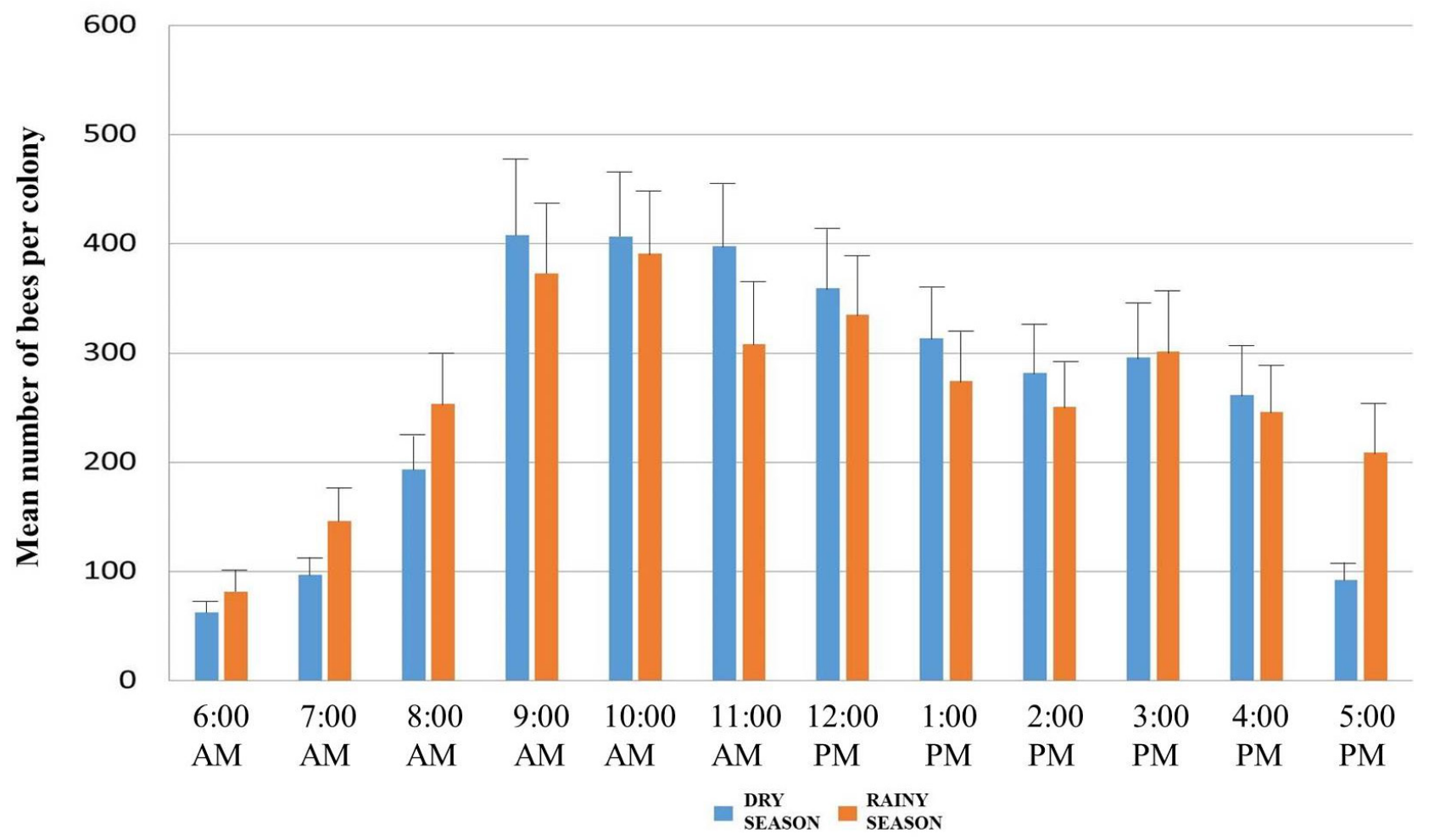

Fig 3. Average number of individuals of Plebeia aff. flavocincta that performed flight activity in relation to time during the dry and rainy season; exit (EXT); trash (TRA); entry with pollen (EWP); entry without pollen (EWoP). Values corresponding to ten minutes of observation.

\section{Discussion}

Our findings with data of daily flight amplitude throughout the year (Fig 1) contrast with studies involving bees of the genus Plebeia in temperate regions. In the state of Rio Grande do Sul, Brazil, P. saiqui exhibit a diapause in periods of scarce resources, and its daytime activity is limited from 08:00 am to 05:00 pm during periods of the year when foraging should be of high priority (Pick \& Blochtein, 2002b). This difference in species behavior probably occurs due to the climatic contrast between the regions. Factors such as temperature and humidity may limit colony flight activities, thus changing foraging time in these bees. Studies with species of genus Plebeia show that limitations of flight activities by climatic factors are mainly related to low temperatures (Kleinert-Giovaninni, 1982; Pick \& Blochtein, 2002b). P. saiqui has a minimum recorded temperature for initial daily flight activities of $11^{\circ} \mathrm{C}$ (Pick \& Blochtein, 2002b) and $P$. emerina was not observed leaving the hive at temperatures below $16{ }^{\circ} \mathrm{C}$ (Kleinert-Giovaninni, 1982). However, this limitation does not occur in places where the minimum temperatures are higher like those seen in tropical regions. Yet, flight activities of $P$. aff. flavocincta only began at a minimum temperature of $23.4{ }^{\circ} \mathrm{C}$ and did not reach the foraging peak until the temperature reached $28^{\circ} \mathrm{C}$ at 09:00 am (Fig 2).
Therefore, this Plebeia species appears to be much more sensitive to low temperatures than other species of the same genus occurring in regions with milder temperatures. Additionally, the small difference between minimum and maximum temperatures required for external nest activities may explain the poor correlations observed between temperature and flight activities of $P$. aff. flavocincta, which is unlike what is observed in other species of the same genus.

The mean annual relative humidity $(73.5 \%)$ in our study is within the optimal parameters recorded for $P$. saiqui (40 to 79\%) (Pick \& Blotchein, 2002b), while the P. emerina bees have a maximum humidity tolerance of $70 \%$ (KleinertGiovaninni, 1982). This demonstrates that bees of $P$. aff. flavocincta are more tolerant to high humidity than other bees of the same genus. Lower relative humidity rates in tropical climates are usually tied to higher temperatures, and therefore may be a cumulative effect of two environmental parameters in this response.

The average wind speed recorded during the year was $3.4 \mathrm{~m} / \mathrm{s}$. Pick and Blochtein (2002b) noticed that P. saiqui showed activity for the values of $0 \mathrm{~m} / \mathrm{s}$ and $9 \mathrm{~m} / \mathrm{s}$, encompassing all of the values observed during this experiment. However, for $P$. emerina it was found that its activities were restricted at speeds exceeding $4 \mathrm{~m} / \mathrm{s}$ (Kleinert-Giovaninni, 1982). In the area of the present study, the wind speed is usually low 
with no major variations. Despite the small size of $P$. aff. flavocincta, this parameter did not constitute a limiting factor to the external activities of the nest.

In studies evaluating the impact of precipitation on bee flying activities it is generally found that rain causes disruption in external movement (Oliveira, 1973; Iwama, 1977; KleinertGiovannini, 1982) or declines in movements (Michener 1974; Kleinert-Giovannini \& Imperatriz-Fonseca; 1986, Hilário et al., 2001). However, Nogueira-Neto et al. (1959) observed A. mellifera, Plebeia sp. and Nannotrigona testaceicornis collecting pollen and nectar in rainy conditions. Similar conditions were observed for Meliponula nebulata by Kajobe and Echazarreta (2005). We observed similar behavior in this study for $P$. aff. flavocincta, when workers collected pollen during light rain. Thus, all climatic parameters measured in our study were within the amplitude tolerated by Plebeia bees and none of them limited the flight activity of $P$. aff. flavocincta bees.

Our analyses showed two major periods of external activities in $P$. aff. flavocincta colonies: one of great bee activity occurring from September to April (Period 1); and other of less external activities by the bees from May to August (Period 2). Period 1 comprised the months of greater availability of food resources in the study area, when the main plant species present at the site were blooming during dry season (Sep-Nov) and also the flowering of most plant species occurring in the beginning and middle of the rainy season (Jan-May). The second period (Period 2), corresponded with the transition period between the rainy season and the dry season, when we found fewer food resources available which is a critical factor for the external activity of bees (Polatto et al., 2014). Thus, the population within the colony was likely larger during Period 1, largely due to the relationship between the general health of the colony and the amount of flight activity quantified (Hilário et al., 2000). We therefore find it is possible to recognize this period of greatest abundance and flight activity as being ideal for splitting colonies.

The differentiation between periods influences both foraging activities by means of association with resource availability and internal hive activities such as egg laying and colony development (Moo-Valle et al., 2001; Hofstede \& Sommeijer, 2006). This is due to collection rates of different trophic resources, implying a lower or higher rate of food storage, which is essential for the provisioning of brood cells and subsequent growth of the colony population.

In the study area there is a great diversity of plant species that flourish throughout the year (Diogo et al., 2014). This area is in a degraded remnant of tableland forest, but maintains a floristic diversity of plant species that respond physiologically in different ways according to seasonality. In addition, the variety of plant species that comprise the diet of $P$. aff. flavocincta impacts its survival strategy. These bees use different floral resources during different periods, potentializing the use of these plants, thus facilitating the maintenance of the population throughout the year (Hrncir \& Maia-Silva, 2013).
Based on what is observed in Fig 2, there is a difference in flight behavior of bees of the genus Plebeia as a function of region. In colder locations bees of the Plebeia genus are influenced by the period of year in both the peak of flight activities and the maximum amplitude of flight hours (Pick \& Blochtein, 2002b).

In the observed pattern the peaks of bees exiting the hive and entering with pollen are similar. This indicates a strategy already observed for other species of stingless bees which imposes a greater effort of collection when there is a greater supply of resources of high nutritional value (MaiaSilva et al., 2015). Variations in peak activity are observed in different species of bees, as well as species in the same genus and within the same species (Pick \& Blochtein, 2002b).

There was no difference between flight behaviors in the dry and rainy seasons, which was likely due to the peaks in collection of trophic resources (Table 2) occurring in both periods. This leads to a similarity in the means of flight activity in the two seasons. The workers of $P$. aff. flavocincta effectively utilized flowering characteristics of both the dry and rainy season. In each of these periods there was a peak in flowering which allowed the colonies to maintain their populations. Therefore, limitations of colony activities were only presented during times when the supply of trophic resources in the field decreased drastically. This could be correlated to periods of transition between the rainy and dry seasons. This period would require more artificial feeding, and preferably, growing other plant species that could provide natural resources during this time of the year.

Finally, our study aimed to investigate the flight activity of the stingless bee $P$. aff. flavocincta in tropical conditions throughout the year as a parameter to evaluate the general state of the colonies and to investigate the role of food resources and environmental factors in their flight activities. We found that colonies of $P$. aff. flavocincta remain active throughout the year and do not present diapause even in periods of food shortage. Therefore, they can be used for both honey production and agricultural pollination throughout the year. We also found that most external activities occur during the period of higher food availability and is not linked to the rainy or dry season, but to a long period of blooming events running through both seasons. While $P$. aff. flavocincta seems to be dependent on higher temperatures to fully perform their activities outside the nest, its external activities were little affected by the environmental conditions. This is probably because meteorological conditions observed in tropical regions vary little throughout the year. Thus, unlike what has been observed in other geographic regions and with other bee species, external activities of $P$. aff. flavocincta is regulated by food availability rather than prevailing weather conditions. Furthermore, we found that flight activities are all strongly correlated with each other. This confirms the importance of the evaluation of flight activities as an indicator of the general health of the colony because it reflects the situation inside the nest in relation to the storage of resources, hygienic behavior and population size. 


\section{Acknowledgments}

This study was financed in part by the Coordenação de Aperfeiçoamento de Pessoal de Nível Superior - Brasil (CAPES) - Finance Code 001. Breno M. Freitas is thankful to CNPq for a Research in Productivity Sponsorship (\#308948/2016-5).

\section{Authors Contribution}

ABS Barbosa - Conceptualization, methodology, validation, data curation, visualization and writing

HM Meneses - Methodology, validation, investigation, formal analysis, data curation, visualization and writing

FL Rosa - Methodology, validation, investigation, writing and visualization

BM Freitas - Conceptualization, methodology, validation, resources, writing and project administration

\section{References}

Amano, K., Nemoto, T. \& Heard, T.A. (2000). What are stingless bees, and why and how to use them as crop pollinators? - a review. Japan Agricultural Research Quarterly, 34: 183-190.

Ascher, J.S. \& J. Pickering (2020). Discover Life bee species guide and world checklist (Hymenoptera: Apoidea: Anthophila). http://www.discoverlife.org/mp/20q?guide=Apoidea_species. (access date: november 9th, 2020)

Bartomeus, I., Ascher, J.S., Wagner, D., Danforth, B.N., Colla, S., Kornbluth, S. \& Winfree, R. (2011). Climate-associated phenological advances in bee pollinators and bee-pollinated plants. Proceedings of the National Academy of Sciences, 108: 20645-20649. doi: 10.1073/pnas. 1115559108

Bomfim, I.G.A., de Melo Bezerra, A.D., Nunes, A.C., de Aragão, F.A.S. \& Freitas, B.M. (2015). Adaptive and foraging behavior of two stingless bee species in greenhouse mini watermelon pollination. Sociobiology, 61: 502-509. doi: 10.13 102/sociobiology.v61i4.502-509

Brunet, J. \& Syed, Z. (2017). Enhancing pollination by attracting and retaining leaf cutting bees (Megachile rotundata) in alfalfa seed production fields. In: Proceedings for the 2017 Winter Seed School Conference, Las Vegas, Nevada. p. 67-73.

Cane, J.H., Dobson, H.E. \& Boyer, B. (2017). Timing and size of daily pollen meals eaten by adult females of a solitary bee (Nomia melanderi) (Apiformes: Halictidae). Apidologie, 48: 17-30. doi: 10.1007/s13592-016-0444-8

de Oliveira Cruz, D., Freitas, B.M., da Silva, L.A., da Silva, E.M.S. \& Bomfim, I.G.A. (2004). Adaptação e comportamento de pastejo da abelha jandaíra (Melipona subnitida Ducke) em ambiente protegido. Acta Scientiarum. Animal Sciences, 26: 293-298. doi: 10.4025/actascianimsci.v26i3.1777

Del Sarto, M.C.L., Peruquetti, R.C. \& Campos, L.A.O. (2005).
Evaluation of the neotropical stingless bee Melipona quadrifasciata (Hymenoptera: Apidae) as pollinator of greenhouse tomatoes. Journal of Economic Entomology, 98: 260-266. doi: $10.1093 /$ jee$/ 98.2 .260$

Diogo, I.J.S., Holanda, A.E.R., de Oliveira Filho, A.L. \& Bezerra, C.L.F. (2014). Floristic composition and structure of an urban forest remnant of Fortaleza, Ceará. Gaia Scientia, 8: 266-278.

Filmer, R.S. (1932). Brood area and colony size as factors in activity of pollination units. Journal of Economic Entomology, 25: 336-343.

Greco, M.K., Spooner-Hart, R.N., Beattie, A.G., Barchia, I. \& Holford, P. (2011). Australian stingless bees improve greenhouse Capsicum production. Journal of Apicultural Research, 50: 102-115. doi: 10.3896/IBRA.1.50.2.02

Heard, T.A. (1999). The role of stingless bees in crop pollination. Annual Review of Entomology, 44: 183-206. doi: 10.1146/ annurev.ento.44.1.183

Heard, T.A. \& Hendrikz, J.K. (1993). Factors influencing flight activity of colonies of the stingless bee Trigona carbonaria (Hymenoptera, Apidae). Australian Journal of Zoology, 41: 343-353. doi: 10.1071/ZO9930343

Hilário, S.D., Imperatriz-Fonseca, V.L. \& Kleinert, A.D.M.P. (2001). Responses to climatic factors by foragers of Plebeia pugnax Moure (in litt.) (Apidae, Meliponinae). Revista Brasileira de Biologia, 61: 191-196. doi: 10.1590/S0034-71082001000 200003

Hilário, S.D., Ribeiro, M.D.F. \& Imperatriz-Fonseca, V.L. (2007a). Efeito do vento sobre a atividade de vôo de Plebeia remota (Holmberg, 1903) (Apidae, Meliponini). Biota Neotropica, 7: 225-232.

Hilário, S.D, Ribeiro, M.D.F. \& Imperatriz-Fonseca, V.L. (2007b). Impacto da precipitação pluviométrica sobre a atividade de vôo de Plebeia remota (Holmberg, 1903) (Apidae, Meliponini). Biota Neotropica, 7: 135-143.

Hilário, S.D., Imperatriz-Fonseca, V.L. \& Kleinert, A. (2000). Flight activity and colony strength in the stingless bee Melipona bicolor bicolor (Apidae, Meliponinae). Revista Brasileira de Biologia, 60: 299-306. doi: 10.1590/S003471082000000200014

Hofstede, F.E. \& Sommeijer, M.J. (2006). Effect of food availability on individual foraging specialisation in the stingless bee Plebeia tobagoensis (Hymenoptera, Meliponini). Apidologie, 37: 387-397. doi: 10.1051/apido:2006009

Hrncir, M. \& Maia-Silva, C. (2013). The fast versus the furiousOn competition, morphological foraging traits, and foraging strategies in stingless bees. Stingless bees process honey and pollen in cerumen pots. Facultad de Farmacia y Bioanálisis, Universidad de Los Andes, 1-13.

IPECE. Instituto de Pesquisas e Estratégia Econômica do Ceará. 
(2017). Perfil Municipal. Dados disponibilizados pelo IPECE. https://www.ipece.ce.gov.br/wp-content/uploads/sites/45/2018/09/ Fortaleza_2017.pdf. (access date: january 2nd, 2019).

IPBES. (2016) Summary for policymakers of the assessment report of the Intergovernmental Science-Policy Platform on Biodiversity and Ecosystem Services on pollinators, pollination and food production.

Iwama, S. (1977). A influência dos fatores climáticos na atividade externa de Tetragonisca angustula (Apidae, Meliponinae). Boletim de Zoologia, 2: 189-201.

Juliani, L. (1967). A descrição do ninho e alguns dados biológicos sobre a abelha Plebeia julianii Moure 1962. Revista Brasileira Entomologia, 12: 31-58.

Kajobe, R. \& Echazarreta, C.M. (2005). Temporal resource partitioning and climatological influences on colony flight and foraging of stingless bees (Apidae; Meliponini) in Ugandan tropical forests. African Journal of Ecology, 43: 267-275. doi: 10.1111/j.1365-2028.2005.00586.x

Kakutani, T., Inoue, T., Tezuka, T. \& Maeta, Y. (1993). Pollination of strawberry by the stingless bee, Trigona minangkabau, and the honey bee, Apis mellifera: an experimental study of fertilization efficiency. Researches on Population Ecology, 35: 95-111.

Kerr, W.E. (1996). Biologia e manejo da tiúba: a abelha do Maranhão. São Luís: Edufma.

Kleinert, A.M., Ramalho, M., Cortopassi-Laurino, M., Ribeiro, M.F. \& Imperatriz-Fonseca, V.L. (2009). Abelhas sociais (Bombini, Apini, Meliponini). Bioecologia e nutrição de insetos-Base para o manejo integrado de pragas, 373-426.

Kleinert-Giovannini, A. (1982). Influence of climatic factors on flight activity of Plebeia emerina Friese (Hymenoptera, Apidae, Meliponinae) in winter. Revista Brasileira de Entomologia, 26: 1-13.

Kleinert-Giovannini, A. \& Imperatriz-Fonseca, V.L. (1986). Flight activity and responses to climatic conditions of two subspecies of Melipona marginata Lepeletier (Apidae, Meliponinae). Journal of Apicultural Research, 25: 3-8. doi: 10.1080/00218839.1986.11100685

Lemos, C.Q. (2014). Abelha Plebeia aff. flavocincta como potencial polinizador do cacaueiro (Theobroma cacao L.) no semiárido brasileiro. Dissertação (Mestrado em Produção Animal) - Departamento de Zootecnia, Universidade Federal do Ceará, Fortaleza, p. 47.

Lichtenberg, E.M., Imperatriz-Fonseca, V.L. \& Nieh, J.C. (2010). Behavioral suites mediate group-level foraging dynamics in communities of tropical stingless bees. Insectes Sociaux, 57: 105-113. doi: 10.1007/s00040-009-0055-8

Magalhães, C.B. \& Freitas, B.M. (2013). Introducing nests of the oil-collecting bee Centris analis (Hymenoptera: Apidae:
Centridini) for pollination of acerola (Malpighia emarginata) increases yield. Apidologie, 44: 234-239. doi: 10.1007/s13592012-0175-4

Maia-Silva, C., Hrncir, M., da Silva, C.I. \& ImperatrizFonseca, V.L. (2015). Survival strategies of stingless bees (Melipona subnitida) in an unpredictable environment, the Brazilian tropical dry forest. Apidologie, 46: 631-643. doi: 10.1007/s13592-015-0354-1

Michener, C.D. (2000). The bees of the world. Johns Hopkins Univ. Press, Baltimore \& London. 913pp.

Michener, C.D. (1974). The social behavior of the bees: a comparative study (Vol. 73, No. 87379). Harvard University Press.

Moo-Valle, H., Quezada-Euán, J.J. \& Wenseleers, T. (2001). The effect of food reserves on the production of sexual offspring in the stingless bee Melipona beecheii (Apidae, Meliponini). Insectes Sociaux, 48: 398-403. doi: 10.1007/PL00001797

Moure, J.S.; Urban, D. \& Melo, G.A.R. (2011). Catálogo de abelhas Moure. http://moure.cria.org.br/. (access date: february 21st, 2019).

Nogueira Neto, P. (1997). Vida e criação de abelhas indígenas sem ferrão (No. 595.799 N778). São Paulo: Nogueirapis, 445 p

Nogueira-Neto, P., Carvalho, A. \& Antunes Filho, H. (1959). Efeito da exclusão dos insetos polinizadores na produção do café Bourbon. Bragantia, 18: 441-468.

Nunes-Silva, P., Hilário, S.D., Santos Filho, P.D. S., \& ImperatrizFonseca, V.L. (2010). Foraging activity in Plebeia remota, a stingless bees species, is influenced by the reproductive state of a colony. Psyche: A Journal of Entomology, doi: $10.1155 / 2010 / 241204$

Nunes-Silva, P., Hrncir, M., da Silva, C.I., Roldão, Y.S. \& Imperatriz-Fonseca, V.L. (2013). Stingless bees, Melipona fasciculata, as efficient pollinators of eggplant (Solanum melongena) in greenhouses. Apidologie, 44: 537-546. doi: 10.1007/s13592-013-0204-y

Oliveira, M.A.C. (1973). Um método para avaliação das atividades de vôo em Plebeia saiqui (Friese) (Hymenoptera, Meliponinae). Boletim de Zoologia e Biologia, 30: 625-631.

Pick, R.A. \& Blochtein, B. (2002a). Atividades de coleta e origem floral do pólen armazenado em colônias de Plebeia saiqui (Holmberg) (Hymenoptera, Apidae, Meliponinae) no sul do Brasil. Revista Brasileira de Zoologia, 19: 289-300.

Pick, R.A. \& Blochtein, B. (2002b). Atividades de vôo de Plebeia saiqui (Holmberg) (Hymenoptera, Apidae, Meliponini) durante o período de postura da rainha e em diapausa. Revista Brasileira de Zoologia, 19: 827-839.

Polatto, L.P., Chaud-Netto, J. \& Alves-Junior, V.V. (2014). Influence of abiotic factors and floral resource availability on daily foraging activity of bees. Journal of Insect Behavior, 27: 593-612. doi: 10.1007/s10905-014-9452-6 
Putra, R. E., Permana, A. D. \& Kinasih, I. (2014). Application of Asiatic honey bees (Apis cerana) and stingless bees (Trigona laeviceps) as pollinator agents of hot pepper (Capsicum annuum L.) at local Indonesia farm system. Psyche: A Journal of Entomology. doi: 10.1155/2014/687979

Ramalho, M., Imperatriz-Fonseca, V.L., Kleinekt-Giovannini, A. \& Cortopassl-Laurino, M. (1985). Exploitation of floral resources by Plebeia remota Holmberg (Apidae, Meliponinae). Apidologie, 16: 307-330.
Slaa, E.J., Chaves, L.A.S., Malagodi-Braga, K.S. \& Hofstede, F.E. (2006). Stingless bees in applied pollination: practice and perspectives. Apidologie, 37: 293-315. doi: 10.1051/ apido: 2006022

Sterk, G., Peters, B., Gao, Z. \& Zumkier, U. (2016). Largescale monitoring of effects of clothianidin-dressed OSR seeds on pollinating insects in Northern Germany: effects on large earth bumble bees (Bombus terrestris). Ecotoxicology, 25: 1666-1678. doi: 10.1007/s10646-016-1730-y

Silva, J.G., Meneses, H.M. \& Freitas, B.M. (2019). Foraging behavior of the small-sized stingless bee Plebeia aff. flavocincta. Revista Ciência Agronômica, 50: 484-492. doi: 10.5935/18066690.20190057 